\title{
Aspen succession and nitrogen loading: a case for epiphytic lichens as bioindicators in the Rocky Mountains, USA
}

\author{
Rogers, Paul C. ${ }^{*}$; Moore, Kori D. ${ }^{2}$ \& Ryel, Ronald J. ${ }^{3}$ \\ ${ }^{1}$ Western Aspen Alliance, Utah State University, Department of Wildland Resources, 5230 Old Main Hill Logan, UT \\ 84322-5230, USA; \\ ${ }^{2}$ Space Dynamics Laboratory, 1695 N Research Park Way, North Logan, UT 84341, USA; \\ E-mailKori.Moore@sdl.usu.edu; \\ ${ }^{3}$ Utah State University, Department of Wildland Resources, 5230 Old Main Hill Logan, UT 84322-5230, USA; \\ E-mailron.ryel@usu.edu; \\ *Corresponding author; Fax: +1 435797 3796; E-mail p.rogers@usu.edu
}

\begin{abstract}
Question: Can lichen communities be used to assess shortand long-term factors affecting seral quaking aspen (Populus tremuloides) communities at the landscape scale?

Location: Bear River Range, within the Rocky Mountains, in northern Utah and southern Idaho, USA.

Method: Forty-seven randomly selected mid-elevation aspen stands were sampled for lichens and stand conditions. Plots were characterized according to tree species cover, basal area, stand age, bole scarring, tree damage, and presence of lichen species. We also recorded ammonia emissions with passive sensors at 25 urban and agricultural sites throughout an adjacent populated valley upwind of the forest stands. Nonmetric multidimensional scaling (NMS) ordination was used to evaluate an array of 20 variables suspected to influence lichen communities.
\end{abstract}

Results: In NMS, forest succession explained most variance in lichen composition and abundance, although atmospheric nitrogen from local agricultural and urban sources also significantly influenced the lichen communities. Abundance of nitrophilous lichen species decreased with distance from peak ammonia sources and the urban center in all aspen succession classes. One lichen, Phaeophyscia nigricans, was found to be an effective bioindicator of nitrogen loading.

Conclusions: Lichen communities in this landscape assessment of aspen forests showed clear responses to long-term (stand succession) and short-term (nitrogen deposition) influences. At the same time, several environmental factors (e.g. tree damage and scarring, distance to valley, topography, and stand age) had little influence on these same lichen communities. We recommend further use of epiphytic lichens as bioindicators of dynamic forest conditions.
Keywords: Community analysis; Macrolichens; Ordination; Ammonia; Phaeophyscia nigricans; Populus tremuloides.

Nomenclature: Lichen nomenclature follows Brodo et al. (2001), except for recent revisions of Xanthomendoza (formerly Xanthoria) by Lindblom (2004, 2006). All other plants follow Welsh et al. (1987).

Abbreviations: ISA $=$ Indicator species analysis; NMS = nonmetric multidimensional scaling.

\section{Introduction}

Investigations of quaking aspen (Populus tremuloides) in western North America have commonly described dramatic landscape-level changes. As the dominant montane hardwood in this region, aspen is threatened by livestock grazing, wild ungulate browsing, fire suppression, (Gallant et al. 2003; Di Orio et al. 2005; Shepperd et al. 2006), and, potentially, by climate warming (Logan et al. 2007). Quantification of change has been controversial, however, as numerous authors have documented both landscape-level losses (Bartos \& Campbell 1998; Gallant et al. 2003; Di Orio et al. 2005) as well as gains (Barnett \& Stohlgren 2001; Manier \& Laven 2002; Kulakowski et al. 2004) in aspen coverage. Both conclusions implicate the primacy of anthropogenic factors but, for the most part, studies have neglected the impacts of change on aspen-dependent species.

Minute ecosystem components may provide useful bioindicators of various human impacts, but are often overlooked in landscape analyses. Lichens 
have been used to monitor human-induced change for nearly 150 years (Hawksworth 2002), and numerous studies have investigated the impacts of air pollutants on lichens (Barkman 1958; Richardson 1992). More recent work has tracked effects of decreases in airborne sulfur dioxide $\left(\mathrm{SO}_{2}\right)$ and increases in ammonia $\left(\mathrm{NH}_{3}\right)$ and nitrogen oxide $\left(\mathrm{NO}_{\mathrm{x}}\right)$ initiated by nitrogen $(\mathrm{N})$ loading (van Herk 1999; Nimis et al. 2002; Jovan \& McCune 2005, 2006) on lichen communities. Impacts from $\mathrm{NH}_{3}$ in rural areas mainly originate from concentrated feedlots and fertilizers, while $\mathrm{NO}_{\mathrm{x}}$ predominates in urban and near-urban settings, arising from both vehicle and industrial sources (Tillman et al. 2001; Fenn et al. 2003b). In addition to air quality studies, lichen communities have been linked to habitat change (Neitlich \& McCune 1997; Rogers \& Ryel 2008), wildlife concerns (Rosso \& Rosentreter 1999), and biological diversity (Will-Wolf et al. 2002; Hedenås \& Ericson 2004).

Recent investigations have explored the impact of changing aspen forest dynamics on epiphytic macrolichen communities in the Interior West, USA (Rogers et al. 2007a; Rogers \& Ryel 2008). Here, we take a wider view of factors affecting lichen community patterns, including temporal aspen changes. In terms of epiphytic lichens, forest succession represents a long-term change at decade or century scales, while other factors of interest (i.e., tree pathogens, bole scarring, air quality, nitrogen loading) are linked to short-term changes. As with most landscape-level studies, there are multiple influences some environmental and some anthropogenic - that affect plant community development. We hope to address factors influencing lichen communities by integrating a network of montane aspen plots where lichens have been sampled with up-wind ammonia monitoring stations near local population and agricultural centers.

Community analysis involves assessing plant species groups as affected by multiple environmental factors (van Haluwyn \& van Herk 2002; McCune et al. 2002). In taking a community approach, we address the following primary questions: (1) How well do lichen diversity and abundance relate to aspen succession? (2) Are local N sources generally, and $\mathrm{NH}_{3}$ specifically, associated with recent changes in aspen lichen communities? (3) If $\mathrm{N}$ loading is affecting the lichen community, how might this impact be manifest alongside long-term changes in aspen forests? The answers to these questions have important ramifications for aspendependent species and may provide useful bioindicators for future ecological monitoring.

\section{Methods}

\section{Study area}

The Bear River Range has a north-south orientation, straddling the Utah and Idaho border, and is about $135-\mathrm{km}$ long and $30-\mathrm{km}$ wide (Fig. 1). These mountains lie in the Southern Rocky Mountains Ecoregion, at elevations of 1370 to $3040 \mathrm{~m}$, and receive precipitation of between 510 and $1020 \mathrm{~mm}$ per year (Bailey 1995). Moisture arrives primarily in the form of winter snowfall. Circulation and storm patterns normally pass through this region from west to east, with seasonal variations of southwest to northwest flow (Eubank \& Brough 1979). Cache Valley, comprised of a small urban center (Logan City), numerous small agricultural towns, and a state university, has a population of approximately 100000 , and lies to the west of the Bear River Range.

The dominant cover of the study area is a mosaic of conifers, hardwoods, and subalpine meadows. Aspen is the primary hardwood of mid- and upper elevations in the Southern Rockies Ecoregion (Rogers 2002). At these elevations, it coexists with subalpine fir (Abies lasiocarpa), Douglas-fir (Pseudotsuga menziesii), lodgepole pine (Pinus contorta), Engelmann spruce (Picea engelmannii), limber pine (Pinus flexilis), and Rocky Mountain juniper (Juniperus scopulorum). Minor hardwoods include bigtooth maple (Acer grandidentatum), Scouler willow (Salix scouleriana), western serviceberry (Amelanchier alnifolia), chokecherry (Prunus virginiana), and mountain mahogany (Cercocarpus ledifolius). The remaining vegetation consists of forest openings containing big sagebrush (Artemisia tridentata) and grass-forb meadows. The understory of aspen forests ranges from lush stands of diverse grass-forb groups, to shrubby cover dominated by snowberry (Symphoricarpos spp.), sagebrush, and mixed assemblages of these groups (Mueggler 1988).

\section{Field methods}

We randomly selected 47 field locations from a base grid of 422 potential plots falling in aspen forest types on the Utah and Idaho digital vegetation maps (USGS 2004, 2005) covering the entire Bear River Range. All plots were between 2134 and $2438 \mathrm{~m}$ asl and we excluded south-facing slopes from our survey to best meet the assumption that all plots should be susceptible to conifer invasion. We considered that sampling conducted at moisture, elevation, or geographic limits of aspen would display atypical successional patterns and likely 


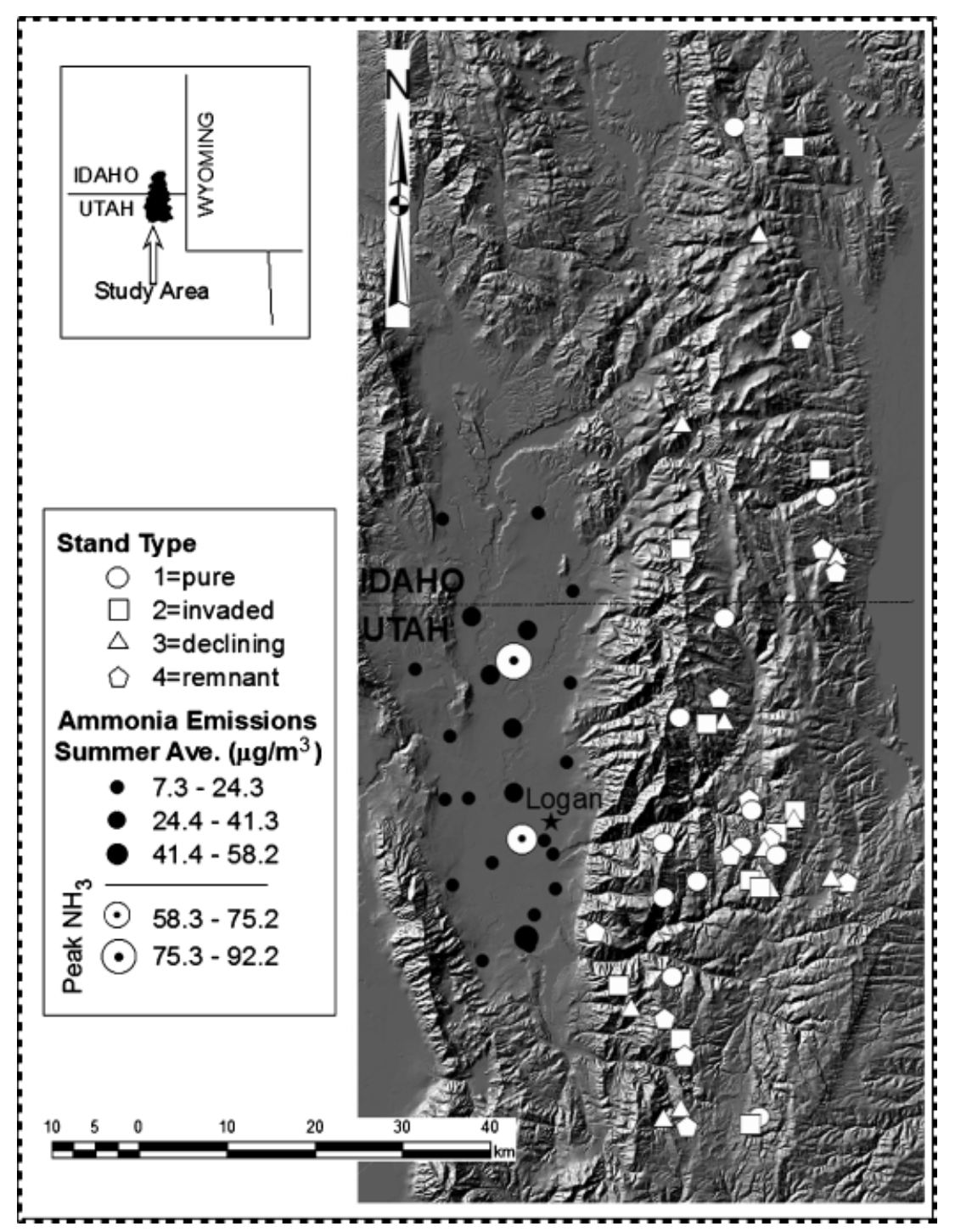

Fig. 1. Study area in the Bear River Range, Utah and Idaho, USA, including location of lichen sampling plots, their stand type designations, ammonia $\left(\mathrm{NH}_{3}\right)$ monitoring stations, and local urban center in Logan, Utah. Stand types represent categories of aspen cover in a successional continuum (see Table 1). Symbols used to represent peak passive air monitoring $\mathrm{NH}_{3}$ sites were derived from the two highest quintiles (equal interval) of readings averaged over three 1-week summer data collection periods.

support lichen communities uncharacteristic of aspen forests. Thus, elevation and aspect limitations were implemented to limit confounding factors associated with succession and moisture. Plots were stratified, based on aerial photographic interpretation, into four broad succession groups: pure aspen, invaded, declining, and remnant (see Table 1 for group criteria; Fig. 1) aspen communities. Further detail of the plot selection procedure can be found in Rogers \& Ryel (2008).

A set of independent ammonia $\left(\mathrm{NH}_{3}\right)$ monitoring sites was located throughout the adjacent (upwind) Cache Valley in Utah and Idaho (Fig. 1). During June and July 2006, 20 gas-phase ammonia
Table 1. Stratification by succession group and cover requirement for study sites in Bear River Range, Utah and Idaho, USA. Sites ranged from nearly pure aspen stands (Pure) to nearly pure mixed conifer (Remnant).

\begin{tabular}{lrrrr}
\hline & \multicolumn{3}{l}{ Succession group } & \\
\cline { 2 - 5 } & Pure & Invaded & Declining & Remnant \\
\hline Group code & 1 & 2 & 3 & 4 \\
Percentage aspen tree cover & $>90$ & $50-90$ & $49-10$ & $<10$ \\
Field plots sampled & 12 & 11 & 12 & 12 \\
\hline
\end{tabular}

samplers (Ogawa Model 3300; Ogawa USA Inc., Pompano Beach, FL, USA) were loaded with pads pre-coated with citric acid solution and deployed to 
yield a spatially resolved representation of ambient ammonia concentrations. Five additional samplers were deployed near locations expected to be strong sources of $\mathrm{NH}_{3}$ (i.e. concentrated agricultural and urban sites). Samplers were deployed for 4 to 7 days per sample period, once in June and twice in July. After exposure, the pads were eluted with deionized water that had been passed through a $0.45-\mu \mathrm{m}$ filter and were analyzed using ion chromatography. Ambient $\mathrm{NH}_{3}$ concentrations were calculated using the diffusion equations given by Roadman et al. (2003). For each location, mean values were calculated by combining the three sample periods representing summer $\mathrm{NH}_{3}$ conditions. A detailed description and validation of the Ogawa passive sampler in scientific studies is provided in Roadman et al. (2003).

Distances from each montane sample plot to the nearest peak $\mathrm{NH}_{3}$ monitoring site, nearest edge of the adjacent Cache Valley, and to the local urban center (Logan City center) were used as surrogates for potential air quality (Fig. 1). Since $\mathrm{SO}_{2}$ has had little impact historically in this non-industrial valley and is of declining importance in industrial locations (Richardson 1992; van Herk et al. 2003; Jovan \& McCune 2006), and ozone $\left(\mathrm{O}_{3}\right)$ has not been conclusively shown to effect lichen communities (Jovan $\&$ McCune 2005, 2006), we did not measure these other gases in the current study. The independence of the source-based $\mathrm{NH}_{3}$ sampling grid from the forest lichen sampling sites constitutes an in situ gradient because of the large variability $(10-90 \mathrm{~km})$ in plot-to-source distances. The distances from the valley edge and urban center to the forest plots represent potential gradients of additional or cumulative sources of $\mathrm{N}$ (i.e. $\mathrm{NH}_{3}, \mathrm{NO}_{\mathrm{x}}$ ) and other pollutants that may affect lichen communities. An additional sampling gradient of the type used in other lichen studies (e.g. Will-Wolf 2002; Jovan \& McCune 2005, 2006) was not used here as it would have introduced the further complication of elevation-precipitation effects on lichen community variability, whereas our design was intended to limit elevation differences to simplify interpretation.

Aspen plot measurements taken from August to October 2006 were of two broad types: stand characterization consisting of location descriptors and tree measures, and macrolichen sampling by species count, voucher collection, and abundance estimation. Tree mensuration was conducted on a 0.02 -ha (7.3-m radius) circular subplot, which was centrally embedded in a 0.38 -ha lichen survey and plot descriptor circle. Collectively, the entire sample area is here referred to as the "plot." Plot descriptors included GPS readings, slope, aspect, stand type, percentage aspen cover, percentage conifer cover, stand age, and aspen age. Diameters of all live and dead trees were measured at breast height. Five canopy cover estimates for aspen and conifers $>2 \mathrm{~m}$ in height were taken at the plot center and $2 \mathrm{~m}$ inside the lichen plot perimeter (33-m radius) at the four cardinal directions. Stand ages were based on coring at least two co-dominant aspen (stand types 1 and 2) and an additional two principal conifer species (stand types 3 and 4). When aspen trees with internal rot were encountered, an alternate tree was cored. Stand ages were calculated by adding 5 years to the breast height average of cored aspen and 10 years to average conifer ages to account for the growth period between ground level and breast height. Estimates of percentage aspen scarring and amount of scar area colonized by lichens were made on the bole surface between 1 and $2 \mathrm{~m}$ from the forest floor. Percentage scarring was calculated as a proportion of this total 1-m area (full circumference) affected. Each aspen recorded was examined for damage agents (i.e. cankers, conks, wounds) that might lead to bole scarring.

Lichen sampling was modeled after the procedure used in the USDA Forest Service, Forest Inventory and Analysis/Forest Health Monitoring program (McCune 2000; Will-Wolf 2002). Briefly, the entire plot area was systematically examined over $2 \mathrm{~h}$ for presence of epiphytic macrolichens $0.5 \mathrm{~m}$ above the forest floor. Lichens were not sampled below $0.5 \mathrm{~m}$ to avoid overlap with terricolous and saxicolous species and their accompanying forest floor influences (i.e. soil type, moisture, leaf litter, vascular plant abundance). This method allows examination of fresh litter fall as a surrogate for upper canopy lichens. At least 40 min were spent traversing the area, the last $10 \mathrm{~min}$ without further new species, before the survey was terminated. We found that an average of $60-75 \mathrm{~min}$ were required for the survey. After completion of the lichen count, each species was assigned a qualitative abundance class for the entire area: $1=1-3$ individuals (distinct thalli); $2=3-10$ individuals; $3=$ between 10 individuals and occurrence on half of all trees/shrubs on the plot; $4=$ more than half of all woody substrates on the plot had the lichen. Previous work found that for sparsely lichen-populated vegetation in large sample areas, visual abundance classes were preferable to continuous cover measures because accuracy was comparable while efficiency was greatly increased (McCune \& Lesica 1992).

Unknown species were collected as voucher specimens for later verification under a dissecting microscope and, when needed, by other lichen 
Table 2. All epiphytic macrolichens recorded on aspen plots $(n=47)$ in the Bear River Range, Utah and Idaho. Species codes include the first two letters of the genus and species epithet, as used in Fig. 2b. Indicator species preference is taken from Rogers \& Ryel (2008), Indicator Species Analysis (Dufrêne \& Legendre 1997) for species preference for aspen stand types (Table 1). Uncommon species $(<5 \%$ of plots) were not analyzed for stand type preference. Significant $P$-values are shown in bold type. ${ }^{*}$ Sensitivity ratings: $\mathrm{N}=$ nitrophilous, $\mathrm{S}=$ sensitive, $\mathrm{I}=$ intermediate, $\mathrm{T}=$ tolerant, $\mathrm{U}=$ unknown. Sources: McCune \& Geiser (1997); McCune \& Jovan (2005); van Herk (1999); Neitlich et al. (2003).

\begin{tabular}{|c|c|c|c|c|c|}
\hline \multirow[t]{2}{*}{ Species } & \multirow[t]{2}{*}{ Species Code } & \multirow{2}{*}{$\begin{array}{l}\text { Frequency of } \\
\text { Presence (\% plots) }\end{array}$} & \multirow{2}{*}{$\begin{array}{l}{ }^{*} \text { Pollution } \\
\text { Sensitivity }\end{array}$} & \multicolumn{2}{|c|}{ Indicator species preference } \\
\hline & & & & Stand type & $P$-value \\
\hline Bryoria fuscescens & BRFU & 27.7 & $\mathrm{~S}$ & Remnant & 0.0010 \\
\hline Candelaria concolor & $\mathrm{CACO}$ & 25.5 & $\mathrm{~N}$ & Declining & 0.3340 \\
\hline Imshaugia aleurites & IMAL & 2.1 & $\mathrm{U}$ & & \\
\hline Letharia columbiana & LECO & 8.5 & $\mathrm{~S}$ & Remnant & 0.5574 \\
\hline Letharia vulpina & LEVU & 29.8 & $\mathrm{~S}$ & Remnant & 0.0246 \\
\hline Melanelia exasperatula & MEEX & 70.2 & $\mathrm{I}$ & Declining & 0.0276 \\
\hline Melanelia subolivacea & MESU & 83.0 & $\mathrm{I} / \mathrm{T}$ & Invaded & 0.1722 \\
\hline Parmelia sulcata & PASU & 2.1 & $\mathrm{~T}$ & & \\
\hline Parmeliopsis ambigua & PAAM & 6.4 & I & Remnant & 0.4598 \\
\hline Phaeophyscia nigricans & PHNI & 80.9 & $\mathrm{~N}$ & Declining & 0.9536 \\
\hline Phaeophyscia orbicularis & PHOR & 2.1 & $\mathrm{~N}$ & & \\
\hline Physcia adscendens & PHAD & 100.0 & $\mathrm{~N}$ & Declining & 0.2414 \\
\hline Physcia biziana & PHBI & 21.3 & $\mathrm{~T}$ & Remnant & 0.6158 \\
\hline Physcia tenella & PHTE & 51.1 & $\mathrm{~N}$ & Declining & 0.6952 \\
\hline Physciella chloantha & $\mathrm{PHCH}$ & 27.7 & $\mathrm{U}$ & Declining & 0.7870 \\
\hline Physconia isidiigera & PHIS & 2.1 & $\mathrm{~T}$ & & \\
\hline Usnea hirta & USHI & 2.1 & $\mathrm{~S} / \mathrm{I}$ & & \\
\hline Usnea lapponica & USLA & 51.1 & $\mathrm{~S} / \mathrm{I}$ & Declining & 0.0042 \\
\hline Usnea spp. & & 2.1 & $\mathrm{~S} / \mathrm{I}$ & & \\
\hline Xanthomendoza fallax & XAFA & 68.1 & $\mathrm{~N}$ & Remnant & 0.5104 \\
\hline Xanthomendoza fulva & XAFU & 89.4 & $\mathrm{~N}$ & Pure & 0.3050 \\
\hline Xanthomendoza galericulata & XAGA & 100.0 & $\mathrm{~N}$ & Declining & 0.8210 \\
\hline Xanthomendoza montana & XAMO & 100.0 & $\mathrm{~N}$ & Pure & 0.0150 \\
\hline
\end{tabular}

experts. We also noted on which tree substrate group, or occasional minor woody species, the lichens were recorded. Vouchers of lichen specimens are stored in the Utah State University herbarium.

\section{Derived variables}

Raw data collected in the field were modified to yield plot-level values. We derived several environmental and lichen community variables post-field survey: aspen and total basal area; average percentage bole scarring and lichen colonization of scars on live aspen; proportion of boles damaged versus undamaged for all live aspen per plot; and plot-level lichen species richness (number of distinct species) and total species abundance (cumulative abundance scores). Ammonia sampling comprising the highest two quintiles (i.e. $40 \%$ of data range, or $>58.2 \mathrm{mg}$ / $\mathrm{m}^{3}$ ), with average summer emissions designated "peak $\mathrm{NH}_{3}$ " sites (Fig. 1). Additionally, we summed, at the plot level, the abundance values of nitrophilous ("nitrogen-loving") lichens, calculated their species richness, and derived their proportion (percentage) in relation to all species. These mea- sures were originally used by Jovan \& McCune (2005), and determination of nitrophilous lichens followed van Herk (1999) and Jovan \& McCune (2005) (Table 2). We further define the term nitrophilous/nitrophyte here to imply lichen species preferring nitrogen-related pollution; whether direct influx on lichen thalli or indirect influence via bark $\mathrm{pH}$ modification.

\section{Analytical methods}

Multivariate analysis was used to explore statistical correlations among several variables including those not meeting normality and variance requirements for parametric treatments - hypothesized to influence lichen community composition in aspen forests. We also ran two types of ordination analysis: indicator species analysis (ISA, Dufrêne \& Legendre 1997) and nonmetric multidimensional scaling (NMS, Kruskal 1964; McCune et al. 2002). ISA was performed as a preliminary analysis to determine any preferences of lichen species for specific aspen stand types (Table 1). 
Our principal variables for NMS, based on previous work (Jovan \& McCune 2005, 2006; Rogers et al. 2007a; Rogers \& Ryel 2008), were forest succession from aspen to conifer, age and basal area of stands, potential air quality (distance to atmospheric $\mathrm{N}$ sources), nitrophilous individuals and indices, and amount of aspen damage related to the level of stem scarring. We used PC-ORD software version 5.0 (McCune \& Mefford 2006) to run NMS on a primary matrix of plots by species and a secondary matrix of plots by environmental and lichen community variables. Only species recorded on at least $5 \%$ of field plots were used in the NMS analysis. The outlier analysis module in PC-ORD was used to eliminate plots with more than two standard deviations from the mean Sørensen distance. Data were subjected to 500 iterations per run using a relative Sørensen distance measure and a random number start. The solution with the lowest stress was derived from 250 runs using real data. "Stress" is a quantitative assessment of final solution monotonicity; or a measure of how well the real data fit the ordination (McCune et al. 2002). The lowest stress solution was then subjected to 250 randomized runs using a Monte Carlo test to evaluate the probability of final NMS patterns being greater than chance occurrences. Orthogonal rotation of the resulting NMS solution was used to maximize correlation between the strongest environmental variables (i.e. Pearson $r$ value) and major axes. The lowest number of dimensions (axes) was selected when adding another dimension would have decreased the final stress by $<5$ (McCune et al. 2002).

\section{Results}

Twenty-four lichen species were found on 47 plots in four aspen succession groups in the Bear River Range (Table 2). Five species were only found once, and one specimen could not be identified beyond the genus (Usnea spp.) because of its stunted growth form or immaturity. Eleven species were recorded on more than half of our plots, although their abundance varied greatly by sample site. Five fruticose species were found, but only one species (Usnea lapponica) was found on more than half of the sample sites (Table 2). P. adscendens, Xanthomendoza galericulata, and Xanthomendoza montana were found on every plot. Fifty-four per cent $(n=13)$ of lichen species were on aspen substrates, although most of these were also found on adjacent conifers. Two species were confined to aspen substrates, and a single occurrence of Physconia isidiigera was found on upland willow, Salix scouleriana.

ISA results describe the strength of preference of each species for a particular aspen stand type (Table 2). These relationships are investigated in detail in Rogers \& Ryel (2008). In brief, most species show a weak affinity for a particular succession class, but five species (B. fuscescens, L. vulpina, $M$. exasperatula, $U$. lapponica, and $X$. montana) were significantly related to three of the four aspen types.

Within Cache Valley, summer ambient $\mathrm{NH}_{3}$ samples ranged from an average of $7.3 \mu \mathrm{m} \mathrm{m}^{-3}$ in a rural town on the west side of the valley to $92.2 \mu \mathrm{m}$ $\mathrm{m}^{-3}$ near a poultry processing plant. In general, the highest values were associated with potential agricultural and municipal sources of $\mathrm{NH}_{3}$. Mean summer average for all sites was $22.8 \mu \mathrm{m} \mathrm{m}^{-3}$ $(\mathrm{SD}=20.8)$. Twenty-two of the $25 \mathrm{NH}_{3}$ sample sites fell in the lowest two quintiles (bottom $40 \%$ ) of the data (Fig. 1). The second peak $\mathrm{NH}_{3}$ value $(68.8 \mu \mathrm{m}$ $\mathrm{m}^{-3}$ ) was located immediately east of an open-air municipal wastewater treatment facility, while a third high value site $\left(58.2 \mu \mathrm{m} \mathrm{m}^{-3}\right)$ - not used as a "peak" $\mathrm{NH}_{3}$ site here - was adjacent to a beef processing plant.

NMS analysis was run on a matrix of 19 species by 46 plots, with a secondary matrix of 20 environmental variables (Table 3 ) by 46 plots. A single plot was eliminated in outlier analysis, and five species were eliminated from the analysis due to their sparse $(<5 \%)$ occurrence on plots (Table 2$)$. The NMS ordination resulted in a three-axes solution, where the final stress and instability were 17.53 and 0.002 , respectively. We assessed stability by plotting a graph of stress versus number of iterations. Stability was reached at approximately 40 iterations from a maximum of 500 iterations. The Monte Carlo test results indicate that this three-dimensional solution using real data was significant $(P<0.01)$. The three axes explain the majority of variability in our lichen community dataset (axis $1: r^{2}=0.19$; axis $2: r^{2}=$ 0.48 ; axis $3: r^{2}=0.10$; total $r^{2}=0.78$; orthogonality $=97.1 \%$ ). Examination of a scree plot using PC-ORD confirmed that the relationship between stress and dimensionality in real versus randomized datasets gave little additional value beyond two dimensions. Because of the relatively small contribution of the third axis and unclear relation to environmental variables, we will not discuss this further.

An ordination joint plot and the categorical variable "stand type" were overlaid on the results of the NMS (Fig. 2a). The centroid of the graph is 
determined from the total number of all species and their abundances in relation to all other species (i.e., "species space"). Environmental variables, presented as direction and strength vectors, are superimposed upon the centroid of the species ordination. The Pearson correlation coefficient $(r)$ values between environmental variables and axes 1 and 2 were calculated (Table 3); environmental variables with $r>0.50$ for either principal axis were considered important contributors to species dis-

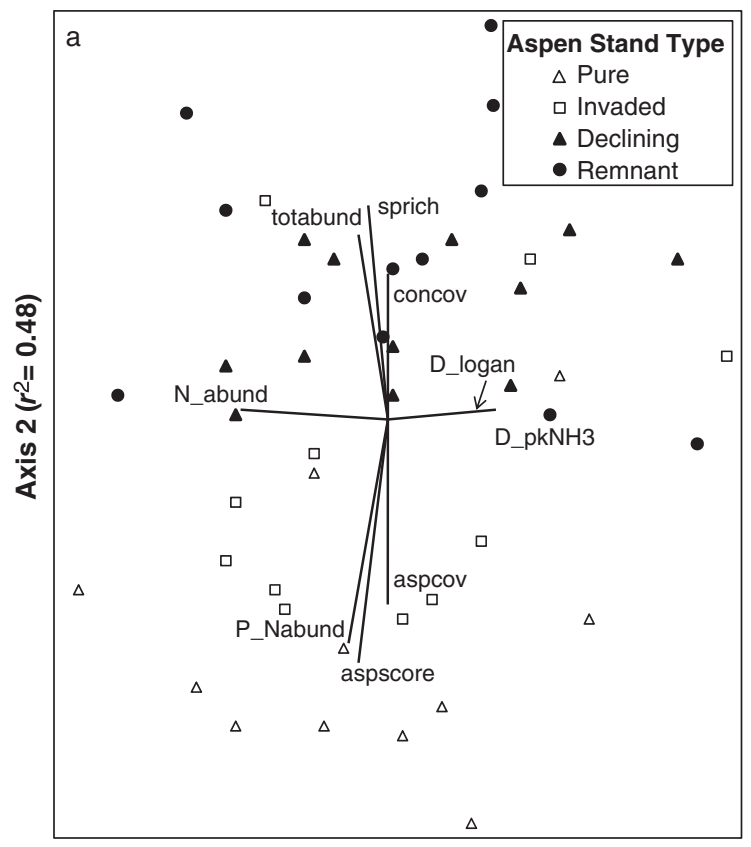

Axis $1\left(r^{2}=0.19\right)$

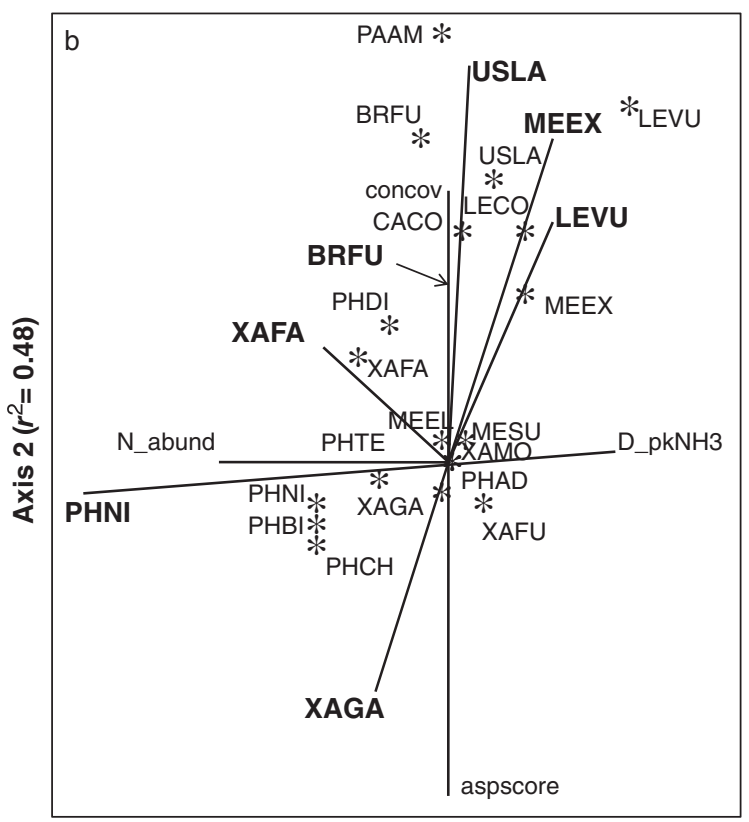

Axis $1\left(r^{2}=0.19\right)$ tributions (Fig. 2a). Overall, axis 2 describes the stronger of the two ordination relationships, corresponding to aspen succession and lichen species richness and abundance. This is verified by the overall ordination and $r$-values for vectors corresponding to axis 2 versus axis 1 (Table 3 ). Generally, plots in declining and remnant stands correlate positively with increased conifer cover and lichen species diversity and abundance in the upper half of the graph (Fig. 2a, Table 3). In contrast, stands closer to pure aspen (stand type 1) are negatively correlated with axis 2 and strongly associated with aspen canopy cover and aspen index score. Percentage nitrogen abundance is closely correlated $(r=-0.78)$ with indicators of pure aspen stands. All measures of basal area and aspen damage/scarring were poorly correlated with axis 2 (Table 3 ).

Axis 1 describes a significant gradient of nitrophilous lichen abundance with distance from both urban and peak $\mathrm{NH}_{3}$ centers (Fig. 2b). The unrelativized index of nitrophilous species abundance decreased $(r=-0.59)$ with increasing distance from the local urban center $(r=0.51)$ and areas of high $\mathrm{NH}_{3}$ concentration $(r=0.52)$.

Important species vectors $(r=<-0.5$ or $>0.5)$ were identified indicating species that may be useful indicators of specific gradient trends (Fig. 2b). Bryoria fuscescens $(r=0.55)$, Letharia vulpina $(r=0.65)$, Melanelia exasperatula $(r=0.75)$, and Usnea lapponica $(r=0.83)$ correlate positively with

Fig. 2. Ordination joint plots from nonmetric multidimensional scaling (NMS) with environmental (a) variables overlaid as vectors on plot stand types in lichen species space, and lichen species (b) plotted as vectors and all species locations in the ordination shown as asterisks $\left(^{*}\right)$. Vector direction and length designate strengths of correlations within the ordination. All environmental and species vectors with $r<-0.5$ or $r>0.5$ are shown (see Table 3). Abbreviations: totabund $=$ Total lichen abundance; sprich $=$ Lichen species richness; $\operatorname{concov}=$ Conifer cover; D_Logan $=$ Distance to urban center $($ Logan, Utah, USA); D_pkNH3 = Distance to peak $\mathrm{NH}_{3}$; aspcov $=$ Aspen cover; aspscore $=$ Aspen index score; P_Nabund = Percentage nitrophilous species abundance; N_abund = Nitrophilous species abundance. Exact orthogonal rotation is used in (a and b), although (a) is enlarged $(2 \times)$ to improve clarity of species names and locations. Selected environmental vectors are displayed in (a) to aid in orientation. Species codes correspond to the first two names of the genus and species epithet (Table 2). Large font, bold type, species codes describe vectors. Usnea lapponica (USLA) has the strongest correlation with axis 1 (succession), and Phaeophyscia nigricans (PHNI) is most strongly correlated with axis 2 (atmospheric nitrogen). 
Table 3. Coefficients of determination $(r)$ between environmental variables, lichen species, and primary ordination axes (see text for details). Variables in boldface for $r>0.5$ or $r<-0.5$.

\begin{tabular}{|c|c|c|}
\hline & \multicolumn{2}{|l|}{$r$ value } \\
\hline & Axis 1 & Axis 2 \\
\hline \multicolumn{3}{|c|}{ ENVIRONMENTAL and LICHEN COMMUNITY VARIABLES } \\
\hline Aspect & -0.006 & 0.074 \\
\hline Aspen basal area per ha & -0.454 & -0.427 \\
\hline Aspen cover & -0.121 & -0.752 \\
\hline Aspen index score & -0.471 & -0.865 \\
\hline Basal area per ha & -0.277 & 0.392 \\
\hline Conifer cover & 0.031 & 0.684 \\
\hline Dead basal area per ha & -0.107 & 0.377 \\
\hline Distance to urban center (Logan) & 0.509 & 0.139 \\
\hline Distance to peak $\mathrm{NH}_{3}$ & 0.523 & 0.113 \\
\hline Distance to nearest valley edge (Cache) & 0.237 & 0.111 \\
\hline Lichen species richness & -0.062 & 0.783 \\
\hline Nitrophilous species abundance & -0.586 & 0.140 \\
\hline Nitrophilous species richness & -0.366 & 0.376 \\
\hline Percentage aspen damage & 0.136 & 0.092 \\
\hline Percentage aspen scars colonized & -0.102 & 0.135 \\
\hline Percentage aspen bole scarring & 0.065 & 0.074 \\
\hline Percentage nitrophilous species abundance & -0.444 & -0.781 \\
\hline Slope & 0.106 & 0.054 \\
\hline Stand age & -0.402 & -0.033 \\
\hline Total lichen abundance & -0.134 & 0.746 \\
\hline \multicolumn{3}{|l|}{ LICHEN SPECIES } \\
\hline Bryoria fuscescens & 0.007 & 0.561 \\
\hline Candelaria concolor & 0.066 & 0.373 \\
\hline Letharia columbiana & 0.101 & 0.197 \\
\hline Letharia vulpine & 0.476 & 0.634 \\
\hline Melanelia elegantula & -0.208 & 0.330 \\
\hline Melanelia exasperatula & 0.488 & 0.734 \\
\hline Melanelia subolivacea & -0.002 & 0.135 \\
\hline Parmeliopsis ambigua & 0.031 & 0.345 \\
\hline Phaeophyscia nigricans & -0.771 & -0.145 \\
\hline Physcia adscendens & 0.129 & 0.164 \\
\hline Physcia biziana & -0.246 & -0.057 \\
\hline Physcia dimidiata & -0.082 & 0.179 \\
\hline Physcia tenella & -0.239 & -0.006 \\
\hline Physciella chloantha & -0.292 & -0.113 \\
\hline Usnea lapponica & 0.270 & 0.830 \\
\hline Xanthomendoza fallax & -0.385 & 0.490 \\
\hline Xanthomendoza fulva & 0.236 & -0.302 \\
\hline Xanthomendoza galericulata & -0.409 & -0.599 \\
\hline Xanthomendoza montana & -0.007 & 0.047 \\
\hline
\end{tabular}

axis 2 and conifer cover, while Xanthomendoza galericulata $(r=-0.62)$ correlates with aspen canopy cover (and aspen index score, Table 3). Axis 1, a gradient of nitrogen loading related to distance from sources, revealed a strong link between abundance of nitrophilous species and Phaeophyscia nigricans $(r=-0.77)$. Other "clean air" lichens, such as Usnea, Bryoria, and Letharia (Neitlich et al. 2003), display a stronger correlation with axis 2, although Melanelia exasperatula and Letharia vulpina exhibit a positive tendency toward clean air metrics (axis 1), both having $r$ values of 0.48 (Fig. 2b, Table 3). Similarly, Xanthomendoza fallax related equally strongly in a positive direction with conifer cover (axis 2) and negatively with distance to pollution sources.

\section{Discussion}

Our results describe two significant gradients determining lichen community composition and abundance in aspen forests of the Bear River Range. Clearly, forest succession plays a dominant role in this regard. Secondarily, we found a pattern of sensitivity to local atmospheric $\mathrm{N}$ sources reflected in several indirect measures of $\mathrm{N}$ loading.

\section{Sampling}

To isolate the successional component of aspen communities, this study targeted putative seral aspen stands and limited sample plots to a 300-m-wide mid-elevation belt, avoiding south-facing aspects that restrict moisture differences that are known to strongly influence lichen community composition (Marsh \& Nash 1979; McCune et al. 1998). Because our method required the presence of some aspen on each plot, we also address how aspen alone affects the lichen community. Prior work in our study area (Rogers et al. 2007a; Rogers \& Ryel 2008) found only two lichen species, Phaeophyscia nigricans and Physcia tenella, exclusive to aspen forest types (i.e., stand types 1 and 2). If advancing succession due to climate change or fire suppression continues (i.e., Bartos \& Campbell 1998), we may witness a gradual loss of these two lichens that favor the aspen habitat (Rogers \& Ryel 2008).

\section{Lichen community change with succession}

By placing successional indices (Rogers \& Ryel 2008) alongside other putative factors, we are able to present relative contributions among several ecological gradients to epiphytic lichen distributions (Fig. 2a, Table 3). These characterizations clearly show the dominant role that succession (aspen to conifer) plays in terms of species richness and abundance, as well as the negative correlation with aspen index scores. In fact, the aspen index score in previous work (Rogers \& Ryel 2008) as well as here, was the strongest response variable to community change during succession. Lichens favoring aspen forest types (i.e. aspen indicators) are located just below the midpoint of the successional gradient (axis 2), while several species that are positively correlated with succession are located near the upper end of the gradient. This general pattern is also illustrated by the results of ISA (Table 2), although ordination results cannot be directly compared because ISA focuses strictly on the succession factor, while NMS looks at numerous factors in "species 
space." Fruticose lichens in our study are exclusively associated with conifers, and more so with conifers in remnant aspen stands, thus they are located furthest from the center (zero value) on the successional gradient. No species display a strong a negative correlation to axis 2 that would indicate a clear preference for pure aspen stands (Table 3, Fig. 2b).

Environmental measures of physiographic position, stand structure and age, tree damage, bole scarring, and level of scar colonization performed poorly in NMS correlations to primary axes (Table 3). While we hypothesized a relationship between stand age, level of scarring, and potential for lichen habitat creation, it appears that aspen stands contain sufficiently varied habitats and that colonization is not limited among the range of successional and potential $\mathrm{N}$ saturation conditions sampled.

\section{Atmospheric nitrogen sources and aspen lichen communities}

Axis 1 characterizes the relation between nitrophilous lichen species and distance from $\mathrm{NH}_{3}$ sources. Distance to urban center implies a general air quality gradient, but admittedly a less clear gradient (Fig. 2a). While some $\mathrm{NO}_{\mathrm{x}}$ contributes to overall local $\mathrm{N}$ deposition, we presume that $\mathrm{NH}_{3}$ constitutes the primary source of $\mathrm{N}$ for the study area, based on the regional models provided by Fenn et al. (2003b) and the predominance of local peak sources. Although $\mathrm{NH}_{3}$ is also present in auto exhausts from diffuse and urban sources, vehicle emissions are presumed to be the prime origin of $\mathrm{NO}_{\mathrm{x}}$ (Fenn et al. 2003b; Jovan \& McCune 2005). Our lichen index, abundance of nitrophilous species, is negatively correlated to axis 1 , and Phaeophyscia nigricans stands out as a strong indicator of $\mathrm{N}$ deposition (Fig. 2b). As distance increased from peak $\mathrm{NH}_{3}$ sources, $P$. nigricans decreased in epiphytic lichen communities, regardless of stand successional stage. Earlier work in the Bear River Range found that $P$. nigricans was the strongest indicator species, displaying more affinity for aspen than conifers stems (Rogers et al. 2007a), although that preference did not hold up when comparing whole stands dominated by these two tree types (Rogers \& Ryel 2008). Melanelia exasperatula and Letharia vulpina show promise as clean air indicators (positively correlated to axis 1), but their primary relation was to the successional gradient (Table 3). It may be that other traditional clean air lichen genera, such as Bryoria and some Usnea species, are already largely depleted from the landscape and give only a weak pollution signal in our analysis.
Why did percentage nitrophilous species abundance perform poorly as an indicator of $\mathrm{N}$ loading (Fig. 2a)? All species comprising the aspen index score are nitrophytes, so when abundance scores of nitrophilous species were relativized to all species recorded their importance became inflated where fewer total lichen species were present (i.e. in pure aspen stands). Thus, a simple abundance sum of nitrophilous lichens gave a clearer picture of $\mathrm{N}$, regardless of total diversity or preference toward aspen-dominated stands. Jovan \& McCune (2005, 2006) probably had more success with a proportional nitrophyte metric because of their much greater species diversity, thus minimizing the "aspen effect" (i.e. low diversity) encountered here.

Axis 1 also addresses air pollution generally versus specific $\mathrm{NH}_{3}$ sources. Distances from each montane sample plot to the nearest edge of the adjacent Cache Valley and the local urban center acted as surrogates for general measures of air quality, including $\mathrm{NO}_{\mathrm{x}}$ sources; primarily automobiles in this area. We found only a weak relationship between lichen communities and our generalized measure of local pollution (distance to nearest valley edge; Table 3). Comparison of values between distance to an urban center and $\mathrm{NH}_{3}$ sources gave a very close relation in statistical strength and orientation to major gradients (Fig. 2a). We note that one of the two areas in Cache Valley with high $\mathrm{NH}_{3}$ is geographically near the urban center, so this might partially explain the correlation of these two measures. Other authors have noted that automobile exhaust, assumed to peak in population centers, is also a source of atmospheric $\mathrm{NH}_{3}$ (Fenn et al. 2003a; Jovan \& McCune 2005, 2006). However, we found marked differences for $\mathrm{NH}_{3}$ monitors in close proximity to our local urban center (22.7 and $11.4 \mu \mathrm{g} \mathrm{m}^{-3}$ ) and a source located $\sim 5 \mathrm{~km}$ west of the city $\left(68.8 \mu \mathrm{g} \mathrm{m}^{-3}\right)$.

We expect that $\mathrm{NH}_{3}$ will not remain in the air, given its high deposition velocity (Fenn et al. 2003a; Roadman et al. 2003), but longer-range transport of the pollutant is likely a result of $\mathrm{NH}_{3}$ conversion to other forms of atmospheric N. Ammonium $\left(\mathrm{NH}_{4}\right)$ wet deposition is believed to impact plant communities between 100 and $1000 \mathrm{~km}$ from its origin (van Herk et al. 2003). These authors found $\mathrm{NH}_{3}$, with an airborne distance limit of perhaps $50 \mathrm{~km}$, is responsible for increases in nitrophilous lichens, while $\mathrm{NH}_{4}$ wet deposition at much lower levels may deplete regional-scale communities of "acidophytes." Acidophytes show a preference for acid bark (van Herk et al. 2003), and three species found in our study (Bryoia fuscescens, Imshaugia aleurites, Usnea 
hirta) were shown to be sensitive to long-range transport of $\mathrm{N}$ in European forests. A key difference, however, may be the strong orographic effect of precipitation in the Southern Rockies Ecoregion. As precipitation increases with elevation, $\mathrm{N}$ deposition rates also increase (Williams \& Tonnessen 2000), potentially accounting for the increase in nitrophilous lichen species found here at montane sites nearer $\mathrm{NH}_{\mathrm{x}} / \mathrm{NO}_{\mathrm{x}}$ sources. Further, although $\mathrm{NH}_{3}$ dry deposition is known to chemically alter tree bark, it is believed that long-range deposition of $\mathrm{NH}_{3}$ in the form of $\mathrm{NH}_{4}$ will not alter bark $\mathrm{pH}$, but will be absorbed directly into lichen thalli via precipitation (van Herk et al. 2003). $\mathrm{NH}_{4}$ wet deposition, because of the distance from sources in the present study, is believed to be at least partially responsible for elevated nitrophytes and reduced acidophytes. It is possible that our limited number of acidophytic lichens may be related to this $\mathrm{NH}_{\mathrm{x}}$ deposition.

\section{Bark $p H$, nitrophily, and lichen communities}

Although we did not measure bark $\mathrm{pH}$, previous research has addressed lichen preferences based on $\mathrm{pH}$ differences in bark on hardwoods and softwoods (Barkman 1958; Martin \& Novak 1999; Jovan \& McCune 2006). Hardwood bark is generally more alkaline than conifer bark and therefore is assumed to attract nitrophilous species (Jovan \& McCune 2006). The species included in our aspen index score (Phaeophyscia nigricans, Physcia tenella, Xanthomendoza fulva, X. galericulata) are all considered to be nitrophilous (Table 2). However, NMS results clearly differentiated between a lichen-based index of $\mathrm{N}$ loading and aspen-to-conifer succession (Fig. 2a and b, Table 3). Thus, although variability in aspen bark pH likely contributes to species use of this substrate, these results suggest a stronger (or additional) effect of airborne nutrients beyond the natural substrate $\mathrm{pH}$.

Variance in bark $\mathrm{pH}$ associated with proximity to bark scars (Barkman 1958; van Dobben \& ter Braak 1998; van Haluwyn \& van Herk 2002) may affect lichen density, as most lichens on quaking aspen in our area occur on old wounds (Martin \& Novak 1999; Rogers \& Ryel 2008). However, lichen habitat on aspen does not appear to decrease with stand age because, as aspen stems thin with advancing succession, larger remnant aspen have greater levels of scarring (Rogers \& Ryel 2008), and conifers also provide a substrate for several nitrophilous lichens.
Finally, Sparrius (2007) provides proximate evidence, via decreases in nitrophytic lichens accompanying mandated $\mathrm{NH}_{3}$ cutbacks in The Netherlands, that $\mathrm{NH}_{3}$ directly modifies bark $\mathrm{pH}$. Other authors have affirmed this hypothesis to varying degrees (Barkman 1958; van Haluwyn \& van Herk 2002; van Herk et al. 2003; Wolseley et al. 2006). We concur with van Herk et al. (2003) that long-distance transport of wet deposition $\mathrm{NH}_{4}$ is a likely contributor to elevated abundance in nitrophyte lichens resulting either from bark $\mathrm{pH}$ modification or via nitrification $\left(\mathrm{NO}_{3}\right)$ of associated mosses. Airborne dust may further contribute to nitrophyte abundance in xeric regions (Barkman 1958; Rosentreter 1990; Frati et al. 2007), although we did not measure this factor in the present study.

\section{Effects of nitrogen loading on aspen ecosystems}

Nitrogen loading in the USA and globally has been expanding in recent decades due to widespread adoption of concentrated animal production facilities and increased use of fertilizer (van Herk 1999; Tillman et al. 2001; Fenn et al. 2003a). One study linked $\mathrm{N}$ deposition from urban pollution to aspen stand expansion in Alberta's parklands (Köchy \& Wilson 2001). While we are uncertain how $\mathrm{N}$ directly influences aspen in our mixed montane forests, we believe that changes are likely to be subtle. Jovan \& McCune $(2005,2006)$ documented a clear gradient of $\mathrm{NH}_{3}$ effects on lichen communities at a broader scale in California. While it appears this pattern is also occurring in our study area, an evolving aspen environment - e.g. studies linking browsing ungulates, fire suppression, and climate to long-term aspen decline (Ripple et al. 2001; Rogers et al. 2007b) - adds a prominent dimension to these community considerations. Where nitrophytes are assumed to favor $\mathrm{N}$-enhanced forests, we might consider how this effect is manifested with limited or declining primary substrates (i.e. aspen trees).

\section{Conclusions and Implications}

Forest succession and indices of $\mathrm{N}$ deposition related to local $\mathrm{NH}_{\mathrm{x}} / \mathrm{NO}_{\mathrm{x}}$ sources explained most of the variation in lichen communities in our Southern Rockies Ecoregion aspen forests study area. The salient contribution of the present study has been to simultaneously evaluate anthropogenic change and ecological processes. These results support the use of epiphytic lichen communities as effective bioindicators of potential $\mathrm{N}$ loading in aspen communities. 
Further, as pollution-recording devices are expensive and concentrated on urban and agricultural systems, an efficient alternative for remote locations is to implement biomonitoring methods such as those employed here. Likewise, ecosystem managers should be cognizant of recent factors (i.e., $\mathrm{N}$ loading) affecting aspen-dependent species while addressing long-term and large-scale issues targeting disturbance regimes and stand trajectories.

Acknowledgements. This work was funded by grants from USDA Forest Service - Rocky Mountain Research Station, USDA Natural Resources Conservation Service, and Utah Agricultural Experiment Station. We thank Dale Bartos, Leila Shultz, Terry Sharik, and Roger Rosentreter for reviewing early drafts of the paper. We wish to acknowledge the contribution of the anonymous reviewers toward improving the final paper. John Lowery, Utah State University GIS/Remote Sensing Lab, helped with geographic data acquisition. Henrik Hedenås, of Umeå University (Sweden), Department of Ecology and Environmental Sciences, was invaluable as a tutor on lichen and European aspen interactions.

\section{References}

Bailey, R.G. 1995. Descriptions of the ecoregions of the United States. U.S. Department of Agriculture, Forest Service, Washington Office, Washington, DC. Misc. Pub. No. 1391.

Barkman, J.J. 1958. Phytosociology and ecology of cryptogamic epiphytes. Van Gorcum \& Company, Assen, NL.

Barnett, D.T. \& Stohlgren, T.J. 2001. Aspen persistence near the National Elk Refuge and Gros Ventre Valley elk feedgrounds of Wyoming, USA. Landscape Ecology 16: 569-580.

Bartos, D.L. \& Campbell, R.B Jr. 1998. Decline of quaking aspen in the Interior West - examples from Utah. Rangelands 20: 17-24.

Brodo, I.M., Sharnoff, S.D. \& Sharnoff, S. 2001. Lichens of North America. Yale University Press, US, New Haven, CT.

Di Orio, A.P., Callas, R. \& Schaefer, RJ. 2005. Fortyeight-year decline and fragmentation of aspen (Populus tremuloides) in the South Warner Mountains of California. Forest Ecology and Management 206: 307-313.

Dufrêne, M. \& Legendre, P. 1997. Species assemblages and indicator species: the need for a flexible asymmetrical approach. Ecological Monographs 67: 345-366.

Eubank, M.E. \& Brough, C.R. 1979. Mark Eubank's Utah weather. Horizon Publishers \& Distributers, US, Bountiful, UT.
Fenn, M.E., Baron, J.S., Allen, E.B., Rueth, H.M., Nydick, K.R., Geiser, L., Bowman, W.D., Sickman, J.O., Meixner, T., Johnson, D.W. \& Neitlich, P. 2003a. Ecological effects of nitrogen deposition in the western United States. BioScience 53: 404-420.

Fenn, M.E., Haeuber, R., Tonnesen, G.S., Baron, J.S., Grossman-Clarke, S., Hope, D., Jaffe, D.A., Copeland, S., Geiser, L., Rueth, H.M. \& Sickman, J.O. 2003b. Nitrogen emissions, deposition, and monitoring in the western United States. BioScience 53: 391-403.

Frati, L., Santoni, S., Nicolardi, V., Gaggi, C., Brunialti, G., Guttova, A., Gaudino, S., Pati, A., Pirintsos, S.A. \& Loppi, S. 2007. Lichen biomonitoring of ammonia emission and nitrogen deposition around a pig stockfarm. Environmental Pollution 146: 311-316.

Gallant, A.L., Hansen, A.J., Councilman, J.S., Monte, D.K. \& Betz, DW. 2003. Vegetation dynamics under fire exclusion and logging in a Rocky Mountain watershed, 1856-1996. Ecological Applications 13: 385-403.

Hawksworth, D.L. 2002. Bioindication: calibrated scales and their utility. In: Nimis, P.L., Scheidegger, C. \& Wolseley, P. (eds.) Monitoring with Lichens Monitoring Lichen. pp. 11-20. Kluwer Academic Publishers and NATO Scientific Affairs Division, London, UK.

Hedenås, H. \& Ericson, L. 2004. Aspen lichens in agricultural and forest landscapes: the importance of habitat quality. Ecography 27: 521-531.

Jovan, S. \& McCune, B. 2005. Air-quality bioindicators in the greater Central Valley of California, with epiphytic macrolichen communities. Ecological Applications 15: 1712-1726.

Jovan, S. \& McCune, B. 2006. Using epiphytic macrolichen communities for biomonitoring ammonia in forests of the greater Sierra Nevada, California. Water, Air, and Soil Pollution 170: 69-93.

Kruskal, J.B. 1964. Nonmetric multidimensional scaling: a numerical method. Psychometrika 29: 115-129.

Kulakowski, D., Veblen, T.T. \& Drinkwater, S. 2004. The persistence of quaking aspen (Populus tremuloides) in the Grand Mesa area, Colorado. Ecological Applications 14: 1603-1614.

Köchy, M. \& Wilson, S.D. 2001. Nitrogen deposition and forest expansion in the northern Great Plains. Journal of Ecology 89: 807-817.

Lindblom, L. 2004. Xanthomendoza. In: Nash, T.H., Ryan, B.D., Diederich, P., Gries, C. \& Bungartz, F. (eds.) Lichen Flora of the Greater Sonoran Desert Region: volume I. pp. 561-566. Lichens Unlimited, Tempe, AZ, US.

Lindblom, L. 2006. Xanthomendoza galericulata, a new sorediate lichen species, with notes on similar species in North America. The Bryologist 109: 1-8.

Logan, J.A., Régnière, J., Gray, D.R. \& Munson, S.A. 2007. Risk assessment in the face of a changing 
environment: gypsy moth and climate change in Utah. Ecological Applications 17: 101-117.

Manier, D.J. \& Laven, R.D. 2002. Changes in landscape patterns associated with the persistence of aspen (Populus tremuloides Michx.) on the western slope of the Rocky Mountains, Colorado. Forest Ecology and Management 167: 263-284.

Marsh, J.E. \& Nash, T.H. 1979. Lichens in relation to the four corners power plant in New Mexico. The Bryologist 82: 20-28.

Martin, E. \& Novak, S.J. 1999. Composition and cover of epiphytic lichens on Pseudotsuga menziesii and Populus tremuloides in southwestern Idaho. Evansia 16: 105-111.

McCune, B. 2000. Lichen communities as indicators of forest health. New Frontiers in Bryology and Lichenology 103: 353-356.

McCune, B. \& Geiser, L. 1997. Macrolichens of the Pacific Northwest. Oregon State University Press, Corvallis, OR, US.

McCune, B. \& Lesica, P. 1992. The trade-off between species capture and quantitative accuracy in ecological inventory of lichens and bryophytes in forests in Montana. The Bryologist 95: 296-304.

McCune, B. \& Mefford, M.J. 2006. PC-ORD: multivariate analysis of ecological data. MjM Software, Gleneden Beach, OR, US.

McCune, B., Rogers, P., Ruchty, A. \& Ryan, B. 1998. Lichen communities for Forest Health Monitoring in Colorado, USA. A report to the U.S. Department of Agriculture, Forest Service, on file at: Rocky Mountain Research Station, Interior West Resource Inventory, Monitoring, and Evaluation Program, Ogden, UT, US.

McCune, B., Grace, J.B. \& Urban, D.L. 2002. Analysis of ecological communities. MjM Software, Gleneden Beach, OR, US.

Mueggler, W.F. 1988. Aspen community types of the Intermountain Region. GTR-INT-250. Intermountain Research Station, USDA Forest Service, Ogden, UT, $135 \mathrm{pp}$.

Neitlich, P., Rogers, P. \& Rosentreter, R. 2003. Lichen community indicator results from Idaho: baseline sampling. RMRS-GTR-103. U.S. Department of Agriculture, Forest Service, Rocky Mountain Research Station, Fort Collins, CO, US.

Neitlich, P.N. \& McCune, B. 1997. Hotspots of epiphytic lichen diversity in two young managed forests. Conservation Biology 11: 172-182.

Nimis, P.L., Scheidegger, C. \& Wolseley, P., (eds.) 2002. Monitoring with Lichens - Monitoring Lichens. Kluwer Academic Publishers and NATO Scientific Affairs Division, London, UK.

Richardson, D.H.S. 1992. Pollution monitoring with lichens. Richmond Publishing Co., Ltd, Slough, UK.

Ripple, W.J., Larsen, E.J., Renkin, R.A. \& Smith, D.W. 2001. Trophic cascades among wolves, elk and aspen on Yellowstone National Park's northern range. Biological Conservation 102: 227-234.
Roadman, M.J., Scudlark, J.R., Meisinger, J.J. \& Ullman, W.J. 2003. Validation of Ogawa passive samplers for the determination of gaseous ammonia concentrations in agricultural settings. Atmospheric Environment 37: 2317-2325.

Rogers, P. 2002. Using Forest Health Monitoring to assess aspen forest cover change in the southern Rockies Ecoregion. Forest Ecology and Management 155: 223-236.

Rogers, P.C. \& Ryel, R.J. 2008. Lichen community change in response to succession in aspen forests of the southern Rocky Mountains. Forest Ecology and Management 256: 1760-1770.

Rogers, P.C., Rosentreter, R. \& Ryel, R. 2007a. Aspen indicator species in lichen communities in the Bear River Range of Idaho and Utah. Evansia 24: 35-43.

Rogers, P.C., Shepperd, W.D. \& Bartos, D. 2007b. Aspen in the Sierra Nevada: regional conservation of a continental species. Natural Areas Journal 27: 183-193.

Rosentreter, R. 1990. Indicator value of lichen cover on desert shrubs. In: McArthur, D.E., Romney, E.M., Smith, S.D. \& Tueller, P.T. (eds.) Proceedings symposium on cheatgrass invasion, shrub die-off, and other aspects of shrub biology and management. GTRINT-276. pp. 282-289. U.S. Department of Agriculture, Forest Service, Intermountain Research Station, Ogden, UT, US.

Rosso, A.L. \& Rosentreter, R. 1999. Lichen diversity and biomass in relation to management practices in forests of northern Idaho. Evansia 16: 97-104.

Shepperd, W., Rogers, P.C., Burton, D. \& Bartos, D. 2006. Ecology, management, and restoration of aspen in the Sierra Nevada. RMRS-GTR-178. U.S. Department of Agriculture, Forest Service, Rocky Mountain Research Station, Fort Collins, CO, US.

Sparrius, L.B. 2007. Response of epiphytic lichen communities to decreasing ammonia air concentrations in a moderately polluted area of The Netherlands. Environmental Pollution 146: 375-379.

Tillman, D., Fargione, J., Wolff, B., D'Antonio, C., Dobson, A., Howarth, R., Schindler, D., Schlesinger, W.H., Simberloff, D. \& Swackhamer, D. 2001. Forecasting agriculturally driven global environmental change. Science 292: 281-284.

USGS. 2004. Provisional digital land cover map for the Southwestern United States. Version 1.0. National Gap Analysis Program, RS/GIS Laboratory, College of Natural Resources, Utah State University, Logan, UT, US.

USGS. 2005. Current distribution of sagebrush and associated vegetation in the Columbia Basin and Southwestern Regions. Version 1.0. United States Geological Survey, Forest and Rangeland Ecosystem Science Center, Snake River Field Station, Boise, ID, US.

van Dobben, H.F. \& ter Braak, C.J.F. 1998. Effects of atmospheric NH3 on epiphytic lichens in The 
Netherlands: the pitfalls of biological monitoring. Atmospheric Environment 32: 551-557.

van Haluwyn, C. \& van Herk, C.M. 2002. Bioindication: the community approach. In: Nimis, P.L., Scheidegger, C. \& Wolseley, P. (eds.) Monitoring with lichens - monitoring lichens. pp. 39-64. Kluwer Academic Publishers and NATO Scientific Affairs Division, London, UK.

van Herk, C.M. 1999. Mapping of ammonia pollution with epiphytic lichens in the Netherlands. The Lichenologist 31: 9-20.

van Herk, C.M., Mathijssen-spiekman, A.M. \& de Zwart, D. 2003. Long-distance nitrogen air pollution effects on lichens in Europe. The Lichenologist 35: 347-359.

Welsh, S.L., Atwood, N.D., Goodrich, S. \& Higgins, L.C. 1987. A Utah Flora. Great Basin Naturalist Memoir \#9. Brigham Young University Press, Provo, UT, US.

Will-Wolf, S. 2002. Monitoring regional status and trends in forest health with lichen communities: the United States Forest Service approach. In: Nimis, P.L., Scheidegger, C. \& Wolseley, P. (eds.) Monitoring with lichens - monitoring lichens. pp. 353-357. Kluwer
Academic Publishers and NATO Scientific Affairs Division, London, UK.

Will-Wolf, S., Esseen, P.A. \& Neitlich, P. 2002. Monitoring biodiversity and ecosystem function: forests. In: Nimis, P.L., Scheidegger, C. \& Wolseley, P. (eds.) Monitoring with lichens - monitoring lichens. pp. 203-222. Kluwer Academic Publishers and NATO Scientific Affairs Division, London, UK.

Williams, M.W. \& Tonnessen, K.A. 2000. Critical loads for inorganic nitrogen deposition in the Colorado Front Range, USA. Ecological Applications 10: 1648-1665.

Wolseley, P.A., James, P.W., Theobald, M.R. \& Sutton, M.A. 2006. Detecting changes in epiphytic lichen communities at sites affected by atmospheric ammonia from agricultural sources. The Lichenologist 38: 161-176.
Received 13 February 2009; Accepted 17 February 2009. Co-ordinating editor: C. D. Canham. 